Studia nad Autorytaryzmem i Totalitaryzmem 43, nr 1

Wrocław 2021

https://doi.org/10.19195/2300-7249.43.1.8

ŁUKASZ DANEL

ORCID: 0000-0001-9715-3377

Uniwersytet Ekonomiczny w Krakowie

lukasz.danel@uek.krakow.pl

\title{
Euroscepticism or nationalism - which better explains the decision of the British to leave the European Union?*
}

\begin{abstract}
The article is dedicated to the 2016 United Kingdom European Union Referendum (known as the Brexit Referendum) that took place on 23 June 2016 and resulted in the majority of the votes cast being in favor of leaving the EU. As a consequence, on 31 January 2020, the United Kingdom of Great Britain and Northern Ireland officially withdrew from the European Union.

The purpose of this article is to try to make an interpretation of Brexit by attempting to answer a question of which of these two factors - Euroscepticism or nationalism - more heavily determined the will of the people and influenced the result of the referendum. Euroscepticism has accompanied the British from the very moment their country became part of the united Europe. The importance of nationalism in turn, analyzed as both English nationalism and British nationalism, has increased significantly in recent years.

Using the collected research material, the author will try to prove the thesis that, in fact, these two factors are inextricably linked and it is very difficult to examine them separately. Euroscepticism, so deeply rooted in the British society, seems to have been - especially in recent years - the driving force of English and British nationalism.
\end{abstract}

Keywords: Brexit, European Union, Great Britain, Euroscepticism, English nationalism, British nationalism.

* The publication was co-financed/financed from the subsidy granted to the Cracow University of Economics. 


\section{Introduction}

At midnight, 31 January, 2020, the UK withdrew from the EU and thus set a precedent in the history of European integration. Although the UK will remain subject to EU law and will continue to be a member of the EU Customs Union and the Common Market until the end of 2020 as part of the transitional period, it is now outside the EU in both political and institutional terms.

Brexit has thus become a fact, despite the impression that the British political elites were incapable of implementing citizens' decision for a long time. Suffice it to say that 3.5 years passed between the announcement of the referendum results and the final withdrawal from the EU, and during that period, the Brexit turmoil cost two British Prime Ministers their political careers and two early general elections were held for the House of Commons. Although such political perturbations are part of democratic political systems and their workings, this has given rise to concerns about the status and quality of the British democracy, previously thought of as a role model in many respects.

Even if the claims about British democracy experiencing a crisis eventually proved much overstated, the question remains as to what made the British people make a decision that shook the foundations of their democracy so much. This is not even a question of whether the decision was right or wrong, a clear answer to this being hardly possible. This is more of a question about the political and social nature of Brexit and thus the factors that made the UK, after 50 years of commitment to processes of European integration, break its ties with the political and economic structures of the united Europe.

The past few years have seen many inquiries which aimed to precisely interpret Brexit and examine the key factors behind the result of the referendum in 2016. This paper looks at two factors that appear to have had a crucial impact on the research problem in question. One of them is Euroscepticism, which has in fact accompanied the British people since they joined the united Europe, and always differed from similar attitudes on the Continent due to British historical, legal and constitutional conditions. The other one is nationalism, or more precisely, English nationalism, although British nationalism is also part of the picture.

This article thus seeks to find out which of these factors - Euroscepticism or nationalism - was the major driver behind the result of the Brexit referendum, the one that might have crucially contributed to Brexit supporters slightly outnumbering their opponents. Based on the collected research material, the author will seek to demonstrate that the two factors were, in fact, inextricably intertwined, and that examining them separately is hardly possible. The British people's deep-rooted Euroscepticism seems to have been the driving force behind both English and British nationalism, especially in recent years. To prove this research hypothesis, the author will employ the historical method, along with content analysis and some institutional and legal analysis. 


\section{Brexit interpretations}

Undoubtedly, from the perspective of the factors which led to it, Brexit is an immensely complex and multilayered phenomenon. It can be scrutinized from a variety of angles, including political, economic, social, historical and cultural. None of these angles alone, however, can show us the whole Brexit picture, each of them being a piece of a larger whole, necessary for us to fully comprehend the reasons why the majority of Britons voted for the UK's withdrawal from the EU.

From the day the referendum result was officially announced, political commentators and numerous researchers studying British social structures and electoral behaviours sought to define a typical Leave voter, or, in common parlance, a Brexiteer. They would determine an array of various social and demographic features characterizing this group of voters and seek correlations to demonstrate which of the features mostly contributed to the referendum result.

As determined in numerous analyses conducted for this purpose, an 'average' Brexit supporter is - with the highest degree of simplification - a voter aged $65+$ who is poorly educated, and low-skilled, and who has a low-paid job, a low social background, and lives in a relatively poor region of the United Kingdom (e.g. in the northern parts of England). This definition of a Leave voter aligns with the commonly promoted narrative that the votes for Brexit were essentially the voice of those who can be thought of as "victims of globalization." They are said to have used the referendum on the UK's further EU membership to show their frustration and dissatisfaction with the reality around them, mainly due to all kinds of injustices they suffer from the beneficiaries of the current political, economic and social order.

However, researchers representing various academic centres, including the London School of Economics and Political Science, argue that this picture is over-simplified. A detailed evaluation of the referendum results points to certain correlations, e.g. the fact that voters of the lower social strata representing the lowest-paid vocational groups were more likely to vote for Brexit. However, upper middle class members consisted of roughly equal numbers of voters supporting or opposing Brexit. One thus cannot prove the argument that the results of the referendum clearly reflected the British divide into various social groups, whereby the ones with greater privilege would clearly support the UK's further EU membership and the ones experiencing greater injustices would reject such a prospect. Such divisions became visible within individual social groups to a greater extent than between those social groups. ${ }^{1}$

1 L. Antonucci, L. Horvath, A. Krouwel, "Brexit was not the voice of the working class nor the uneducated - it was of the squeezed middle", The London School of Economics and Political Science, 13 October 2017, https://blogs.lse.ac.uk/politicsandpolicy/brexit-and-the-squeezed-middle/ (accessed: 10.05.2020). 
The situation is similar if we take into account age groups and educational backgrounds, although trends seem somewhat more evident in this respect. Once again, to argue that Brexit became true because it was voted for mainly by those aged over 65 years would be a great oversimplification, since about $40 \%$ of them voted against it. On the other hand, ca. $30 \%$ of young voters supported the UK's leaving the EU. Nor was Brexit the exclusive voice of the poorer and lesserdeveloped northern part of the United Kingdom, especially northern England, since many voters in the wealthier areas also voted for Brexit, e.g. in southern England. Therefore, building an image of the average Brexit supporter based exclusively on social and demographic variables comes with a risk of oversimplification, or flattening, of that picture, although such an analysis shall not ignore these variables. It is not possible to identify a homogenous group of Brexiters based exclusively on such features. ${ }^{2}$

Therefore, to understand what motivated the Britons who chose to support Brexit, we need to adopt a broader research perspective and transcend the simplified categories used on various occasions to precisely define specific groups of voters. What seems necessary for this purpose is an analysis at the level of values, attitudes and beliefs, especially with respect to Euroscepticism and nationalism, which operate on the basis of interconnected vessels.

\section{British Euroscepticism}

From a definitional point of view, the concept of Euroscepticism appears easy to explain, as it is inextricably connected with reluctance towards the process of European integration set off in Europe shortly after the end of WWII. ${ }^{3}$ Although the concept has become a permanent part of the language of politics, and, since the late 1990s, with the stepped-up integration processes following the enforcement of the Maastricht Treaty, Euroscepticism has come to operate as a scientific term, it is worth noting that such attitudes had been present among political elites and societies of member states of the European Communities a long time before. One can also notice this phenomenon within British society and the state.

Even if the concept of Euroscepticism might at first be easy to define, it takes on a slightly different meaning in various EU member states. This is because the sources of reluctance towards the EU, that is, the foundation of this stance or phe-

2 J. Eichhorn, "Identification with Englishness is the best clue to understanding support for Brexit", The London School of Economics and Political Science, 31 March 2018, https://blogs.lse. ac.uk/politicsandpolicy/the-black-box-of-brexit-identification-with-englishness-is-the-best-clue/ (accessed: 10.05.2020).

3 Cf. R. Riedel, K. Zuba, "Eurosceptycyzm - propozycja konceptualizacji”, Przeglad Europejski 2015, no. 3, p. 26-49; and A. Pleśniarska, "Integracja europejska w obliczu eurosceptycyzmu”, Zeszyty Naukowe Uniwersytetu Ekonomicznego w Krakowie 2017, no. 6, pp. 29-43. 
nomenon, are not identical everywhere and do not always stem from the same factors. This additional assumption allows us to slightly individualize British Euroscepticism and think of it in isolation from similar attitudes observed and studied in the states of the continental Europe, although the attitudes there are not homogenous, either.

In the case of the UK, Euroscepticism essentially boils down to a very simple belief: that the UK's membership in the EU and previously in the European Economic Area was a mistake. This belief accompanied a large part of British society from the very beginning, since 1973, when the UK joined the European Communities. Two years later, in 1975, the country mounted a referendum in which the Brits were asked to say if they really wanted the membership. One might even have the impression that Euroscepticism came into being in that country even earlier, in the late $1950 \mathrm{~s}$, when political elites refused the invitation from other states and did not sign the Treaties of Rome, mainly due to historical and prestige considerations. After the UK eventually joined the European Communities, for almost 50 years of being part of that extensive political and economic project, Britons failed to build their European identity or fully commit to the processes of European integration. This was accompanied by incessant skepticism about political, economic and social advantages apparently coming with such integration. More importantly, for all of those decades, no British government, from the cabinet of Edward Heath to that of David Cameron, built or clearly promoted any kind of narrative to demonstrate the advantages of being part of the European structures; they distanced themselves from those structures, rather than identifying with them. This gap was used by tabloids, mainly those of Rupert Murdoch's media empire, consistently fueling anti-EU sentiments from the early 1980s on, playing on Britons' emotions and using their poor knowledge of the meaning and advantages of European integration. All of this made Euroscepticism take very deep root in the UK. ${ }^{4}$

This Euroscepticism, or at times even Europhobia, was driven by the fear that the British national identity and, most importantly, sovereignty of the British parliament - an institution with a special place in that society's collective consciousness - are seriously endangered by the EU-made laws prevailing over member states' legislations. What seems to be a milestone in the evolution of British Euroscepticism is the Maastricht Treaty, which greatly reinforced the EU and its institutions and was a starting point in 'communitizing' many of its policies and intensifying the cooperation between member states within many different domains. ${ }^{5}$

For the past few years, Euroscepticism has grown stronger and come to be voiced not only by the parties which would base their political identity on criti-

4 A. Heywood, Essentials of UK Politics, Basingstoke-New York 2011, p. 326. For more information about British Euroscepticism, see also: M. Spiering, A Cultural History of British Euroscepticism, Basingstoke-New York 2015; The UK Challenge to Europeanization: The Persistence of British Euroscepticism, eds. K. Tournier-Sol, C. Gifford, Basingstoke-New York 2015.

5 R. Leach, B. Coxall, L. Robins, British Politics, Basingstoke-New York 2011, pp. 273-275. 
cizing the EU (United Kingdom Independence Party, or UKIP, and the Brexit Party, established in 2019), but also a large part of the political mainstream, playing a key role especially in the Conservative Party. It was pressure from the politicians clearly opposing the UK's further EU membership that forced Tory leader David Cameron to first resign from the Conservative Party's affiliation with the European People's Party (Christian Democrats) in the European Parliament and then mount a nationwide Brexit referendum. The pre-referendum campaign was dictated by Euroscepticists and dominated by politicians such as UKIP leader Nigel Farage and Michael Gove, representing the Eurosceptic wing of the Conservative Party, as well as the UK's current Prime Minister, Boris Johnson. They were the faces of the Leave camp and, as it turned out, were then trusted by the majority of the referendum voters.

The very pro-Brexit campaign in a very strong and effective way leveraged Euroscepticism, embedded in the British society for many decades and nourished by politicians, commentators and influential journalists who set the tone for the public debate and consequently built up a negative image of the EU. It was a campaign addressing human emotions, making use of stereotypes and populist slogans to make the British society fear the EU and the UK's further EU membership. One of the claims was that, upon leaving the EU, the UK would have a better way to control its borders and protect itself against the influx of immigrants, not only from the Middle East but also from Central and Eastern Europe; this coincided with the peak of the migration crisis. The campaign also heavily stressed the financial aspect and the fact that, under the EU rules in place, the UK contributed to the common EU budget more than it received from it in the form of various programmes and funds. Politicians pushing for Brexit argued that British taxpayers' money should not be transferred to Brussels, as it could be better used within the UK, e.g. to support housing policy, education and, above all, healthcare.

The critique of various aspects of the EU membership has become the leitmotif of the Leave campaign. It seems that there was no need to develop any grand political agenda. To be successful, it was enough to aptly capitalize on the traditional British Euroscepticism, which manifested itself even before the vote, although not to the extent it did in 2016. This is why the EU, along with its excessive bureaucracy and harmful interference with trade relations (both between member states and between the EU and non-member states), and, consequently, the violation of the principles of free trade and free competition so important to the British people came under immense criticism. It is also worth mentioning that the very idea of supra-nationality, one of the pillars of European integration, legally limits the sovereignty of EU member states and the operational independence and freedom of the institutions of the state authorities. This idea clearly contradicted the way British people viewed their state and the way it should function. What takes a special place in the British collective consciousness is the British parliament and 
British courts and tribunals, rather than the European Parliament and the European Court of Justice.

Eurosceptic attitudes were not only expressed by politicians. Traditionally, a significant role was played by the media, including the tabloids, which employed quite a simplified vision of the world and delivered a clearly negative picture of the EU. Furthermore, all kinds of social initiatives and movements, just as politicians and the media, used the fact that an average British person tends to know little about the EU, the way it works and the advantages of EU membership. Under such conditions, the use of simplifications or stereotypes, playing on emotions, fueling fear and capitalizing on the deep-rooted Euroscepticism to achieve the political goal seems to be quite an easy task.

\section{English nationalism and Brexit}

Over the past few years, Europe has seen a rise in popularity of parties and political movements employing nationalist rhetoric. Their main political goal is to build a brand new social and political order based on the idea of a nation state. Anything that limits those states or endangers their full sovereignty is regarded as a source of evil to be ruthlessly fought. For obvious reasons, the EU has a special place in these narratives. What evidences the power of nationalistic movements is primarily their growing social position and, consequently, improving election results, including in the European Parliament elections.

In spite of its natural isolation from the Continent, such attitudes also apply to the UK. Hence, the British decision to leave the EU is also being considered in this context, namely the rebirth of the nationalist idea and the rising wave of populism, which Brexit both generated and resulted from. ${ }^{6}$ At some level, the Brexit decision was also meant to demonstrate Brits' rebellion against democracy, globalization and London political elites, which sacrificed British interests for the interests of the supra-national European Union. ${ }^{7}$ What seems particularly interesting and noteworthy is the analysis of Brexit from the perspective of nationalism, both its English and British versions.

English nationalism boils down to the easy belief that Englishmen make up a nation that has played a special role in the history of Europe and the world at large. English nationalists, who like to think of themselves as English people first and then as Britons, prioritize the promotion of English people's cultural unity and

${ }^{6}$ Ł. Danel, "Polityczne konsekwencje populizmu na przykładzie Brexitu", [in:] Powszechny system ochrony praw czlowieka $w$ dobie kryzysu demokracji liberalnej, eds. J. Jaskiernia, K. Spryszak, vol. 1, Toruń 2020, pp. 328-329.

7 Cf. C. Calhoun, "Populism, Nationalism and Brexit", [in:] Brexit: Sociological Responses, ed. W. Outhwaite, London-New York 2017, pp. 57-76. 
looking after their own interests. In the social and political realm, this nationalism manifests itself in the efforts of various more or less formal political groups and movements that promote English culture, history and language. The attachment to English tradition and the very fact of belonging to the English nation is absolutely the highest value to them, making them proud of England and the English people.

Well-rooted in English literature and writing, this idea has certain historical foundations and justification, since at certain periods of the long and often complicated British history, England was a proud and sometimes even powerful nation state. ${ }^{8}$ Contemporarily, within the British realm itself, English nationalism is taking on a special significance in the context of the discussion on the devolution and the consequent damage suffered by England as a result of those reforms. Many English people believe that the legal and institutional empowerment of Scotland, Wales and Northern Ireland effectuated during Tony Blair's and Labour Party's rule was a historical injustice to England. What is a side-effect to the devolution is the rise in the nationalistic belief that England, devoid of its power, is being used by the other states of the United Kingdom, which rely on England and London, e.g. in financial terms. This belief crops up in recurrent discussions of the so-called West Lothian Question, which informs various ideas about the development of an independent English state or at least establishment of a separate English parliament to make laws just for the English part of the United Kingdom. ${ }^{9}$ These discussions go far beyond the world of academia and journalism, as evidenced by the fact that in 2015, the British House of Commons introduced into the rules of its order of business a procedure allowing the implementation of a certain variant of the concept referred to as English Votes for English Laws (EVEL).

The discussion on this topic will likely continue regardless of the decision made by the Britons in the referendum of 2016. Nevertheless, in a slightly broader perspective, Brexit is often interpreted and referred to as a manifestation of English nationalism, which would imply that nationalism has crucially contributed to the final outcome of the referendum. English people, indeed, clearly provided greater support for the UK to leave the EU than Welsh people did, let alone Scots or the Northern Irish electorate. The English people voting for Brexit outnumbered the English people voting against it by close to 2 million (53.4\% vs. $46.6 \%$ ). The Welsh voting for Brexit also outnumbered those voting against it (52.5\% vs. $47.5 \%$ ), but Scots and Northern Irish people voiced a different view. In the case of Scotland, the ratio was $62 \%$ against Brexit vs. $38 \%$ for it, and in Northern Ireland, it was $55.8 \%$

${ }^{8}$ For more information about English nationalism, see e.g.: J. Black, English nationalism: A Short History, London 2018; K. Kumar, The Making of English National Identity, Cambridge 2003.

9 Cf. for instance: Ł. Danel, "Brytyjskie dylematy konstytucyjne 'pytania z West Lothian”", Studia Polityczne 2017, no. 4, pp. 109-127; M. Russell, G. Lodge, Westminster and the English Question, London 2005. 
vs. $44.2 \%{ }^{10}$ The fact that English people account for $84 \%$ of British society (the Welsh $-5 \%$, Scots $-8 \%$, citizens of Northern Ireland - 3\%) implies that, based on these number alone, we can risk the thesis that the decision to leave the EU was made to a disproportionately higher extent by the English people compared to the pro-Leave votes from other parts of the United Kingdom.

This argument obviously does not necessarily mean that the key role was played in this case by English nationalism, but, on the other hand, a more in-depth analysis of this phenomenon and an inquiry into this potential correlation seem justifiable, all the more so as the campaign for the referendum of 2016 made abundant use of images alluding to English national symbols, such as the English flag (the red Saint George's Cross against a white background), a red rose, the English emblem of a lion, and the white cliffs of Dover. Various other features and symbols evocative of English culture and lifestyle were promoted, too.

It is a fact that identification with 'Englishness' explains the reasons behind many English people's supporting Brexit in the referendum better than the attempt to describe them with social and demographic features, mentioned earlier herein. Research done following the referendum permits the conclusion that the English people strongly connected to their English national identity supported Brexit to a greater extent than those who do not attach such great importance to this identity. More than $70 \%$ of Englishmen who viewed their English identity as the highest value voted for Brexit, while over $80 \%$ of those who stress their English identity to a smaller extent voted against Brexit. ${ }^{11}$

This points to a very interesting conflict of national identity, which manifested itself on the occasion of the referendum of 2016. Traditionally, English people were more willing to recognize themselves as Brits (or at least as being both English people and Brits) than the Welsh, inhabitants of Northern Ireland and - most importantly - Scots, who have a strong sense of separate national identity. However, over the past few decades, this sense of 'Britishness' faded away a great deal for English people. Professor Michael Kenny points out that 'Englishness' — a narrower identity that seems more conservative - is more exclusive and cliquey. Now, 'Britishness', a much broader identity, is clearly more inclusive and open. ${ }^{12}$ Consequently, those thinking of themselves as English people, associating themselves with the narrower identity, were more willing to vote for Brexit, as shown by the aforementioned studies, among others. And conversely, the identification with the broader, British identity definitely correlated to a lower extent with the willingness to leave the EU. This differentiation permitted the thesis that Brexit is a manifestation and creation of English nationalism.

$10 \mathrm{https} / /$ www.electoralcommission.org.uk/who-we-are-and-what-we-do/elections-and-referendums/past-elections-and-referendums/eu-referendum/results-and-turnout-eu-referendum (accessed: 12.05.2020).

11 J. Eichhorn, op. cit.

12 M. Kenny, The Politics of English Nationhood, Oxford 2016. 


\section{British nationalism}

One obviously cannot deny the existence of English nationalism, but, compared to other brands of nationalism, this one is pretty peculiar, manifesting itself on the occasion of the referendum result. Each brand of nationalism, carrying expectations regarding the development of one's own statehood, is marked by five features: a deep sense of injustice with the current state of affairs; a clear concept of a distinctive national identity, even if made up; a common narrative about the country's past, largely imagined; new elites waiting for their turn; and a vision of the future society that will be better since it will govern itself. The first of these features, the sense of the English people's deep dissatisfaction about their status as part of the United Kingdom, is the only one that applies to English nationalism as a phenomenon that underlies Brexit. The other four are virtually non-existent. In cultural terms, 'Englishness' is by no means endangered, nor does it need to be empowered politically, since it is recognizable globally; neither is there a shared and consistent narrative about the past, even if efforts are made to build it based on various historic figures or events. It is equally hard to identify new expectant political elites that would become a pillar of a new English state. And the vision of a future, self-governing English society independent of the EU has been developed based on a few loose populist slogans (e.g. more money on public spending, less money on immigrants etc.), rather than some comprehensive model of social and economic state policies. ${ }^{13}$

The aforementioned arguments substantiate the thesis that it would be a great oversimplification to seek to explain Brexit with English nationalism. Even if 'Englishness' was a significant factor behind garnering support for the idea of the UK leaving the EU (as was voters' belonging to specific social and occupational groups, voters' age or their more conservative views), Brexit occurred not only because of the decision made by the Englishmen alone, and it should thus be treated as a UKwide problem. Therefore, the question of Britishness crops up again, and not just in the context of national identity, since this determined the division between Brexit proponents and opponents to a very low extent. However, examining this decision as one made by all Britons - as a manifestation of their concerns and doubts opens up an avenue for demonstrating the nexus between the motivations of the voters with the phenomenon of British nationalism.

This nationalism is based on the assumption that some British nation exists and the political and cultural unity of that nation should be promoted and the interests of all British people taken care of. Obviously, this nationalism is harder to define than English nationalism and its power is much weaker, but it has solid foundations and a social and political base. We can trace its roots to the anti-immigrant

13 F. O'Toole, "Brexit is driven by English nationalism. And it will end in self-rule", The Guardian, 19 June 2016, https://www.theguardian.com/commentisfree/2016/jun/18/england-eu-referendum-brexit (accessed: 15.05.2020). 
demands formulated by the British National Party, often referred to as a nationalist, ultra-nationalist or even neo-fascist party, and part of the British political scene to this day. British nationalism has been promoted as a progressive idea by representatives of the Conservative Party, including former Prime Minister David Cameron, a politician who officially did not support Brexit but is recognized as one of its fathers and, as it turned out, also its political victims.

Undoubtedly, this nationalism played a significant role in the referendum of 2016 as one of its key pillars; the fear of the UK being flooded by immigrants was skillfully used by the leaders of the Leave campaign. Within a slightly broader perspective, we could even risk the thesis that the UK's EU membership has, to some extent, contradicted the vision, or illusion, of British power from the very beginning. Since a vast share of British political elites believed that it would be possible to build the position of the British state in the post-WWII period upon the remains of the Empire, as mentioned earlier, the UK was not among the founders of the original European Communities. And then, for nearly 50 years after the UK's joining the Communities in 1973, each subsequent cabinet sought to consistently protect this British national identity to meet social expectations. Therefore, British nationalism, too, explains why the UK joined the European Communities so late and, secondly, in a way, why it eventually left the EU following the referendum decision in 2016.

\section{Interdependence between Euroscepticism and nationalism - final conclusions}

In the case of the Brexit referendum, Euroscepticism and nationalism acted as interconnected vessels, intertwined and complementary to each other. Thus, it is not possible to unequivocally answer the question posed at the beginning of this article; that is, "which of the two factors contributed to the decision British people made in the referendum of 2016 to a greater extent?". The conducted analysis thus shows that essentially, these phenomena are inextricably combined with each other and can be hardly considered in isolation.

It is also justifiable to claim that Euroscepticism has been the driving force behind English nationalism for the past several years, which grew a lot more intense with the enforcement of devolution reforms. This kind of nationalism in a way accelerated Eurosceptical attitudes: reluctance towards European integration, a sense of alienation from the EU, a sense of having a small impact on the decisions made by EU institutions, and concerns about phenomena such as excessive immigration and increasingly higher member states' dependence on the decision-making centre in Brussels. This close interdependence between English nationalism and Euroscepticism was actually palpable throughout the UK's involvement in the pro- 
cesses of European integration, mutual relationships between the United Kingdom and European Communities and the EU never being easy. ${ }^{14}$

The culminating point was the referendum on the UK's further EU membership, held on 23 June, 2016. On the one hand, its result can be seen as unexpected but, on the other, it proved the power of British Euroscepticism and nationalism driven by the reluctance to European integration. In the pre-referendum campaign, Brexit supporters aptly used these two phenomena to secure the intended result. The Leave camp reiterated the belief that the UK, especially England, does not need the EU any longer and can fare better out of it.

Let us also point out that the referendum of 2016 was a milestone in the growth of English and British nationalism, and Brexit significantly strengthened both British identity and the identities of the inhabitants of various UK countries. At the British level, it was visible, for instance, on the occasion of the prolonged negotiation between the British government and representatives of European institutions regarding the conditions under which the UK would leave the EU. This increasingly annoyed British people who wished for the completion of the process initiated with the referendum to set the UK free from Brussels and overcome the many bureaucratic barriers contradicting the result of the democratic vote, or the people's will. Hence, for many Britons, Brexit became part of the national identity and reinforced pride in being British. In the past few months, we have also observed the growing significance of the national identity not just in English people, but also the Scots, the Welsh and the Northern Irish people. This is evidenced by the early election for the House of Commons held on 12 December, 2019. In Scotland, the Scottish National Party (SNP) strengthened its dominant position at the cost of two major British political parties, with SNP leader Nicola Sturgeon officially requesting London to permit a second independence referendum in Scotland. ${ }^{15}$ In Northern Ireland, politicians representing the nationalist parties won more parliamentary seats than those of the unionist parties for the first time since 1921. Compared to other parts of the UK, Welsh nationalism is much weaker and lacks solid political representation, but one can see the Welsh fractions of the two main political parties, especially of the Welsh Tories, who secured the highest electoral result in the past century, shift towards increasingly nationalist positions. ${ }^{16}$

${ }^{14}$ Cf. B. Wellings, English Nationalism and Euroscepticism: Losing the Peace, Oxford-New York 2012.

15 S. Carrell, "Sturgeon demands Scottish independence referendum powers after SNP landslide", The Guardian, 13 December 2019, https://www.theguardian.com/politics/2019/dec/13/nicolasturgeon-to-demand-powers-for-scottish-independence-referendum (accessed: 19.05.2020).

16 P. Cockburn, "How nationalism is transforming the politics of the British Isles", CounterPunch, 31 December 2019, https://www.counterpunch.org/2019/12/31/how-nationalism-is-transforming-the-politics-of-the-british-isles/ (accessed: 20.05.2020). 
Brexit should not be viewed and scrutinized in terms of a one-off decision made by the majority of British people who attended the nationwide referendum of 23 June, 2016. Brexit is a climax of a long process of the UK leaving the EU, a process which began the day Brits joined the European Communities. This process was essentially underpinned by two mutually reinforcing phenomena: Euroscepticism and nationalism, both at the English and the British levels.

Abundant evidence shows that Brexit has amplified and solidified these attitudes. Euroscepticism will continue to exist because the UK, now formally outside of the EU, will closely work with it in its own interest. Now, nationalism - both English and British - has existed independently of the EU and, as demonstrated above, the events of the past few years merely strengthened these nationalist attitudes, and they did so across the UK. Time will show what consequences all of this will bring for Britons; many things show, however, that the future of the British state, for instance in terms of its unity, appears bleak.

\section{Bibliography:}

Antonucci L., Horvath L., Krouwel A., "Brexit was not the voice of the working class nor the uneducated - it was of the squeezed middle", The London School of Economics and Political Science, 13 October 2017, https://blogs.lse.ac.uk/politicsandpolicy/brexit-and-the-squeezedmiddle/ (accessed: 10.05.2020).

Black J., English Nationalism: A Short History, London 2018.

Calhoun C., "Populism, Nationalism and Brexit", [in:] Brexit: Sociological Responses, ed. W. Outhwaite, London-New York 2017, pp. 57-76.

Carrell S., "Sturgeon demands Scottish independence referendum powers after SNP landslide", The Guardian, 13 December 2019, https://www.theguardian.com/politics/2019/dec/13/nicola-sturgeon-to-demand-powers-for-scottish-independence-referendum (accessed: 19.05.2020).

Cockburn P., "How nationalism is transforming the politics of the British Isles", CounterPunch, 31 December 2019, https://www.counterpunch.org/2019/12/31/how-nationalism-is-transforming-the-politics-of-the-british-isles/ (accessed: 20.05.2020).

Danel Ł., "Brytyjskie dylematy konstytucyjne 'pytania z West Lothian'”, Studia Polityczne 2017, no. 4 , pp. 109-127.

Danel Ł., "Polityczne konsekwencje populizmu na przykładzie Brexitu”, [in:] Powszechny system ochrony praw człowieka $w$ dobie kryzysu demokracji liberalnej, eds. J. Jaskiernia, K. Spryszak, vol. 1, Toruń 2020, pp. 319-330.

Eichhorn J., "Identification with Englishness is the best clue to understanding support for Brexit", The London School of Economics and Political Science, 31 March 2018, https://blogs.lse. ac.uk/politicsandpolicy/the-black-box-of-brexit-identification-with-englishness-is-the-bestclue/ (accessed: 10.05.2020).

Heywood A., Essentials of UK Politics, Basingstoke-New York 2011.

https:/www.electoralcommission.org.uk/who-we-are-and-what-we-do/elections-and-referendums/ past-elections-and-referendums/eu-referendum/results-and-turnout-eu-referendum (accessed: 12.05.2020).

Kenny M., The Politics of English Nationhood, Oxford 2016. 
Kumar K., The Making of English National Identity, Cambridge 2003.

Leach R., Coxall B., Robins L., British Politics, Basingstoke-New York 2011.

O'Toole F., "Brexit is driven by English nationalism. And it will end in self-rule", The Guardian, 19 June 2016, https://www.theguardian.com/commentisfree/2016/jun/18/england-eu-referendum-brexit (accessed: 15.05.2020).

Pleśniarska A., "Integracja europejska w obliczu eurosceptycyzmu", Zeszyty Naukowe Uniwersytetu Ekonomicznego w Krakowie 2017, no 6, pp. 29-43.

Riedel R., Zuba K., "Eurosceptycyzm — propozycja konceptualizacji”, Przeglad Europejski 2015, no. 3, pp. 26-49.

Russell M., Lodge G., Westminster and the English Question, London 2005.

Spiering M., A Cultural History of British Euroscepticism, Basingstoke-New York 2015.

The UK Challenge to Europeanization. The Persistence of British Euroscepticism, eds. K.TournierSol, C.Gifford, Basingstoke-New York 2015.

Wellings B., English Nationalism and Euroscepticism: Losing the Peace, Oxford-New York 2012.

Studia nad Autorytaryzmem i Totalitaryzmem 43, nr 1, 2021

(C) for this edition by CNS 